$$
\begin{gathered}
\text { 高エネルギーイオン照射による } \\
\text { アルミニウム合金の硬さ制御 }
\end{gathered}
$$



光田 智昭* . 岩瀬 彰宏**

Journal of The Japan Institute of Light Metals, Vol. 62, No. 4 (2012), 170-176

(c) 2012 The Japan Institute of Light Metals

\title{
Hardness control of aluminum alloys by means of high energy ion irradiation
}

\author{
Tomoaki MITSUDA* and Akihiro IWASE**
}

Keywords: hardness, ion irradiation, radiation enhanced segregation, effect of ion irradiation on thermal aging, $3 D$ atom probe

\section{1.はじめに}

アルミニウム合金の材料の強化, 主に硬さを向上させる手 段として，析出現象を用いた時効熱処理が一般的に使われて

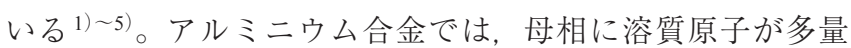
に固溶する温度（T1）に保持（溶体化処理）した後急冷し て得られた過飽和固溶体を, 溶質固溶度の低い温度 $(T 2$, $T 2<T 1$ ）で熱処理（時効処理）して析出相を形成させ，これ によって生じる強化を硬化 (強化) 処理として利用している。 この熱処理を行った際に, 準安定過飽和固溶体から核生成・ 成長によって析出相が生じる場合と, 不安定過飽和固溶体か ら，核生成を伴わずに濃度の摇らぎが発達して析出相が形成 される場合とがあるが，多くのアルミニウム合金では前者が 該当する場合が多い。

一方, 材料に電子線や中性子線, イオンビームなどの高エ ネルギー放射線を照射すると, 材料中の原子や電子にエネル ギーが与えられ, 電子の高密度励起や原子結合の切断, さら には原子の移動が起こり, 材料の微細構造や性質が変化す る ${ }^{6)}$ 7)。本研究で利用する照射促進偏析現象 (radiation enhanced segregation）もその一つである。照射促進偏析とは, 放 射線照射によって生じた格子欠陥（原子空孔，格子間原子） が，材料中の添加元素とカップリングし，格子欠陥の拡散と ともに添加元素も拡散, 偏析する現象である。この現象は,

(1) 添加元素の拡散が, 熱的に拡散, 偏析する温度よりは るかに低い温度で起こる

（2）照射された領域のみで起こる

（3）非熱平衡過程であるため, 熱的偏析に比べて微細な偏 析物が得られる
などの特徵をもつ。材料中の微細な偏析物は, 転位との相互 作用の観点からは，材料強度に大きな変化を与える ${ }^{6), 7) 。 ~}$

照射促進偏析現象は, 原子炉を構成する重要な構成要素の 一つである圧力容器鋼において, 原子力発電プラントの高経 年化に伴う不純物や添加元素の偏析によって生じる材料の硬 化や脆化の原因として考えられている ${ }^{8)}$ 。

このように照射促進偏析は, 材料機能の劣化というマイナ スのイメージをもった現象であったが，材料改質の観点か ら, この現象を用いれば, 上に述べた特徽を利用して比較的 低温で，しかも照射領域のみを硬化させることが可能である ことから ${ }^{9)}$, 今までの手法とは異なった材料強化法としての 利用が可能であると考える。そこで，特性の中でも硬さに着 目し, 時効硬化型アルミニウム合金を利用して, 照射促進偏 析に起因する硬さ変化について調べた。

本稿では，主に2017アルミニウム合金（ジュラルミン） に高エネルギーイオン照射を行うことによって起こる硬さ特 性と組織変化を, 元来広く用いられている時効熱処理との比 較を交えて紹介する ${ }^{10)}$ 。また，照射と時効熱処理を加える ことにより，より大きな硬さ変化が得られた結果も合せて示 す11)。さらに, 6000系, 7000系アルミニウム合金のビッカー ス硬さのイオン照射効果の結果にも触れる。

\section{2. 高エネルギーイオン照射実験}

本研究では, 高エネルギーイオン照射を放射線照射手法と して用いている。そこでまず，イオン照射を行う際に用いる 加速器を紹介する。

我々の研究では, 主に日本原子力研究開発機構 高崎量子 応用研究所のタンデム加速器を用いている。高電圧で負イオ

\footnotetext{
*大阪府立大学大学院工学研究科 物質・化学専攻マテリアル工学分野 大学院生 (†599-8531 大阪府堺市中区学園町 1-1)。Graduate Student, Department of Materials Science, Osaka Prefecture University (1-1 Gakuen-cho, Naka-ku, Sakai-shi, Osaka 599-8531).

**大阪府立大学大学院工学研究科 (堺市)。Department of Materials Science, Osaka Prefecture University (Sakai-shi, Osaka).

受付日：平成23年10月24日受理日：平成23年11月28日
} 
ンを加速し, イオンの電荷を負から正に変換して, 次に正イ オンを加速する装置を総称してタンデム加速器という ${ }^{12)}$ 。 タンデムとは，2頭立ての馬車を意味する言葉であり，負イ オンとして加速したのち, 荷電変換で正イオンにしたものを 続けて加速する点に由来する。

図1(a)に, 日本原子力研究機構高崎量子応用研究所の タンデム加速器の模式図を示す。イオン源で生成した負イオ ンを加速するために超高真空に保たれた初段加速管に入射 し, 負イオン加速管入口まで到達させる。到達した負イオン は, 正の高電圧ターミナルに向けて加速させる。高電圧ター ミナルでは負イオンが電子ストリッパ（炭素薄膜あるいは窒 素ガス層）で多数の電子が剥ぎ取られ正イオンに変換された 後, 正イオン加速管で再び加速され高エネルギーとなる。本 加速器では, 高電圧を発生させるのに, 絶縁性の高いペレッ トをチェーン状にしたものを高速回転することによって高電 圧ターミナルに正電荷を移送・蓄積する方法を用いる。本実 験では，正確な照射量および均一なビームが要求される。正 確な照射量は，試料を取り囲むように置かれた二次電子サプ レッサを用いて，負電圧をかけることにより飛出した二次電 子を電流測定部に押戻し，正確な電流を得ることによって得 ている。また, マグネティックビームスキャナにより $x, y$ 方向にビームを振ることによって，濃淡のない均一なビーム を得ることができる。照射される試料はビームライン末端に 設置された真空チャンバ内におかれる。図1(b) に，高崎量

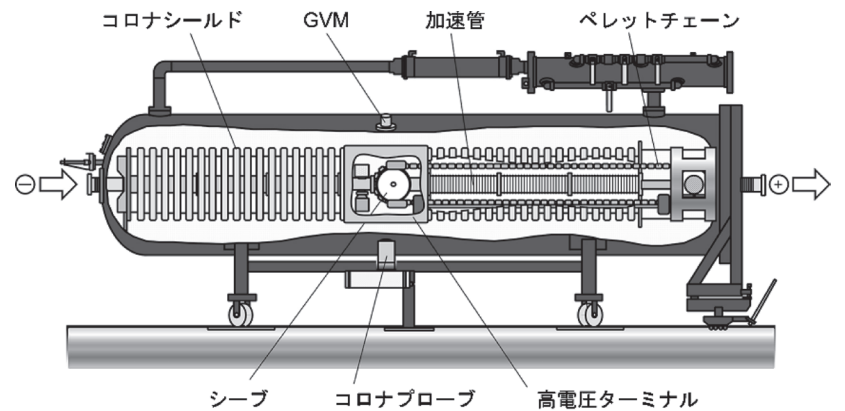

(a)

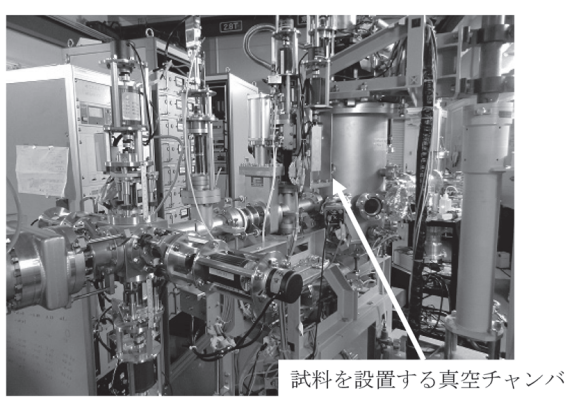

(b)

図1 (a) 日本原子力研究開発機構 高崎量子応用 研究所タンデム加速器の模式図, (b) TA ビー ムラインの末端に設置された照射チャンバ
子応用研究所タンデム加速器の TA ライン末端に設置された 真空チャンバの写真を示す。

また，照射ホルダに取付けられた試料について図2に示 す。銅製のホルダにカーボンテープで試料を貼付け, $10 \mathrm{~mm} \times$ $10 \mathrm{~mm}$ の正方形のビームを試料 1 つずつに照射していく。照 射時に，ビーム位置を試料の中心からずらすことにより，任 意に照射領域を決めることができる。また，イオンビームは， エネルギー，イオン種，ビーム量など，さまざまなパラメー 夕を有し，それらを正確に制御することによって照射条件を 細かく変化させることが可能となる。なお, 今回の実験では, イオンビーム照射を室温で行っている。照射中の温度上昇は わずかであり，熱時効を起こすほどのものではない。

\section{2017 アルミニウム合金（ジュラルミン）のイオ ン照射効果 ${ }^{10}$}

\section{1 マイクロビッカース硬さ計による硬さ測定}

ここでは, $10 \mathrm{MeV}$ のう素イオン照射を施した過飽和 2017 合金の硬さ測定を行った結果を示す10)。硬さ測定には マイクロビッカース硬さ計を用い, 荷重 $25 \mathrm{gf}$, 保持時間 $10 \mathrm{~s}$ の条件で測定を行った。照射条件は表 1 に示す通りである。 イオン照射は照射領域を任意に決めることができるという利 点を活かし，左半分を照射領域，右半分を未照射領域とした 試料の硬さ測定の結果を図3に示す。イオン照射領域のみの 硬さが大きく変化していることがわかる。また硬さのイオン 照射量依存性を示したグラフが図4である。少ない照射量で 硬さは大きく変化し，その後も緩やかに増加し続ける。

次に, イオン照射と従来の時効熱処理に関して, 両者のプ ロセス時間に対する硬さの変化の挙動を比較してみよう。図 5 は, $150^{\circ} \mathrm{C}$ および $180^{\circ} \mathrm{C}$ で熱時効したときの硬さの時間変

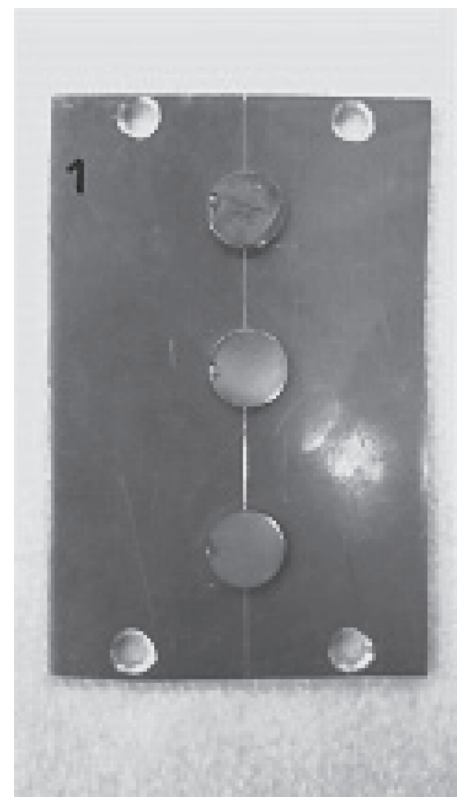

図2 照射ホルダに取付けられた2017合金試料

表 1 イオン照射条件

\begin{tabular}{c|l|l|l|l}
\hline \hline エネルギー & 照射イオン種 & 照射量 & ビームカレント & 照射温度 \\
\hline $10 \mathrm{MeV}$ & $\mathrm{I}\left({ }^{(3+}\right)$ イオン & $3.0 \times 10^{13} \sim 1.0 \times 10^{16} \mathrm{ion} / \mathrm{cm}^{2}$ & 150 particle nA & 室温 \\
$5 \mathrm{MeV}$ & $\left.\mathrm{Al}{ }^{(2+}\right)$ イオン & $3.0 \times 10^{13} \sim 3.0 \times 10^{15} \mathrm{ion} / \mathrm{cm}^{2}$ & 150 particle nA & 室温 \\
\hline
\end{tabular}




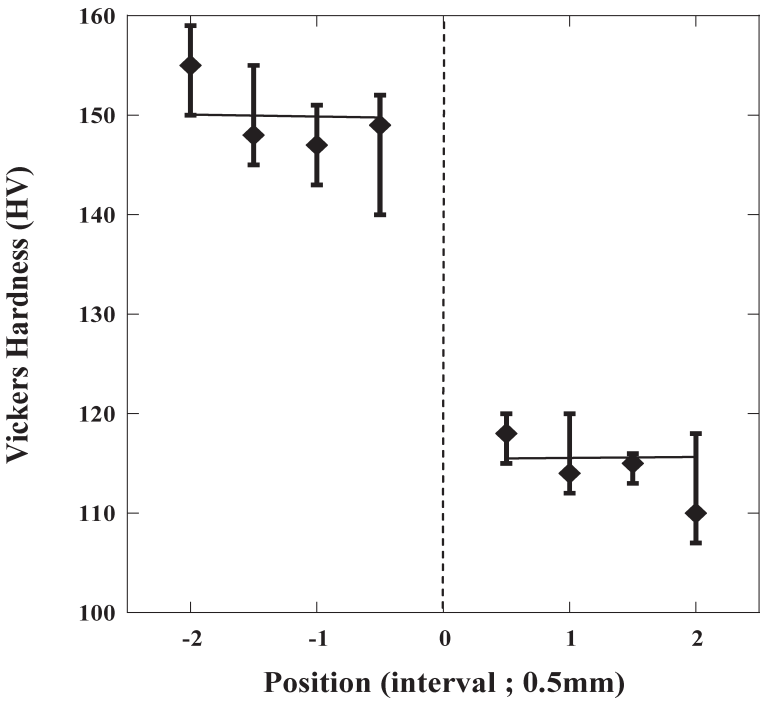

図3 $10 \mathrm{MeV}$ よう素イオン照射した2017合金の硬 さ分布。左半分が照射領域，右半分が未照射 領域である。照射温度は室温, 照射量は $3.0 \times 10^{15} / \mathrm{cm}^{2}$

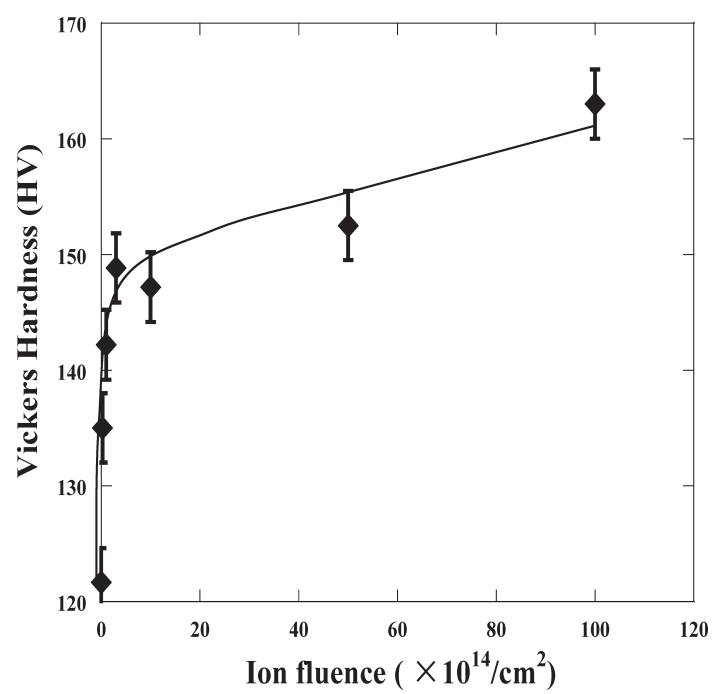

図4 $10 \mathrm{MeV}$ よう素イオン照射した2017合金のマ イクロビッカース硬さの照射量依存性

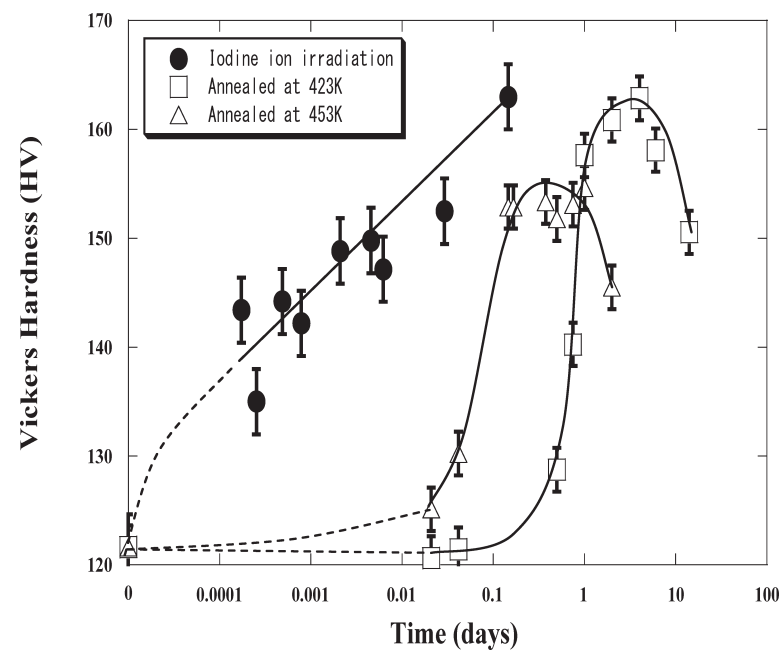

図5 $10 \mathrm{MeV}$ よう素イオン照射した2017合金と時 効熱処理を施した2017合金の硬さ変化のプロ 七ス時間依存性
化を室温で $10 \mathrm{MeV}$ よう素イオン照射した場合と比較したも のである。このグラフから, イオン照射は, 熱時効の場合に比 べ圧倒的に短時間で高い硬さを実現していることがわかる。 熱時効処理でも，温度を上げればより短時間で硬さの増加が 見られるが, その場合, ピーク硬さは低くなる。イオン照射 では，短時間で高い硬さを実現しているため，熱処理とは別 の機構で硬化が起こっていると考えられる。

\subsection{3 次元アトムプローブ法による組織観察 ${ }^{10)}$}

そこで，2017合金の $10 \mathrm{MeV}$ よ素イオン照射による硬さ 変化に対応する組織変化を観察した。イオン照射による組織 変化の観察には，3次元アトムプローブ法を用いた。3次元 アトムプローブ法は，材料中の原子 1 個 1 個について，その 3 次元位置座標と元素の種類を調べることができる手法であ る ${ }^{13), 14)}$ 。位置座標についてはサブナノメートルの分解能を 持ち, 水素や炭素などの軽元素をはじめ, 全元素に対してほ ほ同等の検出感度を有している。このため, 電子顕微鏡など 他の手法では調べることが難しい微細な析出や偏析などを極 めて高精度に測定および分析することができる。図6は，(a) 未照射試料，（b）時効 $\left(150^{\circ} \mathrm{C}, 5\right.$ 日）試料および, (c) $10 \mathrm{MeV}$ よう素イオン照射（照射量 $1.0 \times 10^{15} / \mathrm{cm}^{2}$ ) 試料に対するアト ムプローブ測定によって得られた 3 次元原子マップである。 熱時効試料に関しては，板状の $\mathrm{CuAl}_{2}$ とみられる化合物や針 状の $\mathrm{Mg}_{2} \mathrm{Si}$ とみられる化合物などの数 $10 \mathrm{~nm}$ から数 $100 \mathrm{~nm} の$ 比較的大きな析出物が見られる。それに対して，よう素イオ ン照射試料に関しては，未照射試料と比べ大きな変化は見ら れず種々の原子が均一に分布しているように見える。そこ で，それぞれの試料に関してクラス夕解析を試みた。クラス 夕抽出条件は，探索距離 $0.60 \mathrm{~nm}$, 最小原子数 20 とした。そ の結果を図7に示す。この図によると, 未照射試料（図7(a) ) では，抽出されたクラスタがほぼないのに対し，よう素イオ ン照射試料（図 7 (c)）では, 平均直径が $2.9 \mathrm{~nm}$ の $\mathrm{Cu}, \mathrm{Mg}, \mathrm{Si}$ など添加元素を多く含む微細クラスタが試料中に均一に分布 していることがわかる。また， $150^{\circ} \mathrm{C} ， 5$ 時間の熱時効を施 した試料（図7(b)) では, 図6においても見られた大きな析 出物以外のナノスケールの微細クラスタは見られない。この 観測結果から, 熱時効試料では, 数 $10 \mathrm{~nm}$ 程度の大きな析出 物によって転位のピン止め効果が生じて硬さが増加したのに 対し，照射試料では，ナノメートルスケールの微細クラスタ が，試料中に高密度かつ均一に分散することで，転位に対す るきわめて有効な障害となり，短時間の熱時効では実現でき ないような硬さの上昇をもたらしたと考えられる。

図 8 は, $10 \mathrm{MeV}$ よう素イオン照射試料（照射量 $1.0 \times 10^{15}$ / $\left.\mathrm{cm}^{2}\right)$ におけるよう素原子の3 次元原子マップである。よう 素原子は，その侵入深さ付近で均一に分散していることがわ かる。照射によって試料中に導入されたよう素原子の原子濃 度は 0.03 at $\%$ となった。これは，照射量と試料表面からよう 素イオンが侵入する深さおよび試料の密度から求めた原子濃 度 $0.033 \mathrm{at} \%$ とほぼ一致する。このような, 照射によって試 料中に蓄積されたよう素原子が硬さの増加をもたらした可能 性がある。そこで，2017合金の大部分を占めるアルミニウ ムを照射イオンとして用いる実験を行った。このような照射 実験をセルフイオン照射実験とよぶ。セルフイオン照射の場 合，それが試料内に蓄積したとしても，もともと存在した原 子の個数に比べると割合としては極く微量であるため, イオ 




(a)

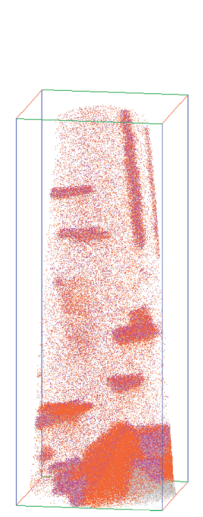

(b)

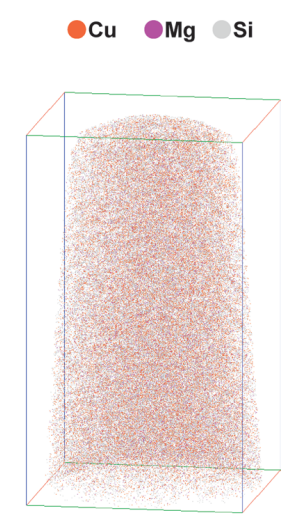

(c)
図6アトムプローブ測定によって得られた2017 合金の 3 次元原子マップ。(a) 未照射試料, (b) 熱時効試料，時効温度は $150^{\circ} \mathrm{C}$ ，時効時 間は 5 日間, (c) $10 \mathrm{MeV}$ よう素イオン照射試 料, 照射量は $1.0 \times 10^{15} / \mathrm{cm}^{2}$

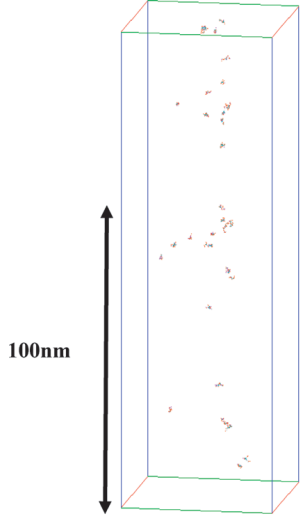

(a)

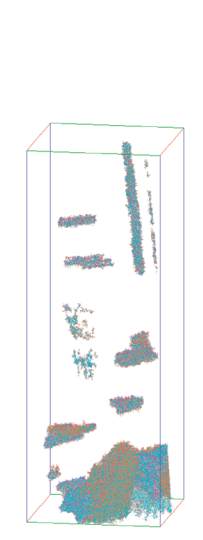

(b)
OCu $\odot \mathrm{Mi}$ OA

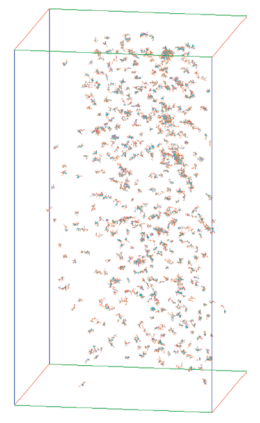

(c)
図7 アトムプローブ測定によって得られた2017合 金のクラス夕解析結果。(a) 未照射試料, (b) 熱時効試料, 時効温度は $150^{\circ} \mathrm{C}$, 時効時 間は5日間, (c) $10 \mathrm{MeV}$ う素イオン照射試 料, 照射量は $1.0 \times 10^{15} / \mathrm{cm}^{2}$



図8 $10 \mathrm{MeV}$ よう素イオンを $1.0 \times 10^{15} / \mathrm{cm}^{2}$ 照射した 2017 合金中のよう素原子の3 次元マップ



図9 $5 \mathrm{MeV}$ アルミウムイオン（セルフイオン）に よる2017合金の硬さの弾性的付与エネルギー 密度依存性。比較のため, $10 \mathrm{MeV}$ よう素イオ ン照射の結果もプロットしている

ンの蓄積効果は問題にならない。照射イオンとして $5 \mathrm{MeV}$ ア ルミニウムイオンを用いた実験結果を図9に示す11)。なお， アルミニウムイオンの照射条件は表 1 に示している。眓9の 横軸は照射量ではなく，照射によりターゲット材料に付与さ れたエネルギー密度（厳密に言えば，弾性的相互作用によっ て付与されたエネルギー密度）である。四９には，10 MeV よう素イオン照射の結果もプロットした。眓9に示された結 果は, イオン照射による2017合金の硬さ変化は, イオン種 によらず，材料に付与されたエネルギー密度に依存するもの であり，このことから図3～図50実験結果は，よう素原子 蓄積効果ではないことがわかる。さらに，イオン照射した試 料における硬さ増加の原因としては, 材料母結晶中の照射欠 陷によることが考えられる。イオン照射によって生成された 格子間原子や原子空孔の拡散・集合により，転位ループなど の2次欠陷集合体が生じる。これらは, 添加元素の析出物同 様，転位の運動に対する障害となりうる。そこで，純アルミ ニウムとアルミニウムに銅を数\%添加した二元合金を作成 して，よう素イオン照射実験を行い，ビッカース硬さを測定 した。その結果，銅を含まない純アルミニウムでは，イオン 照射による硬さの変化はほとんど見られず，銅を添加した試 料では，照射による硬さの増加がみられた。同様の結果は，


オン照射実験においても得られている15)。これらの結果は, 材料母結晶における照射欠陷の硬さに対する寄与はほとんど ないことを示している。以上のことから, 四3〜眓5, 眓9に 示したイオン照射による硬さの増加の主要因は, 図7(c) にみ られる微細ナノスケールクラスタであることが明確となった。

\section{3 高エネルギーイオン照射による硬さ制御プロセスの特徵}

上で述べたように，イオン照射では時効熱処理と比べて， はるかに短時間かつ室温で時効熱処理と同程度の硬さの向上 が見られることがわかった。イオン照射による硬さ変化の特 徴はこのほかにもある。それは，照射によってエネルギーが 付与される領域のみの硬さを制御できることである。

図 10 は照射損傷解析コードSRIM2010 ${ }^{16 ）}$ を用いて計算し た弾性的エネルギー付与の試料表面から深さ方向にかけての 


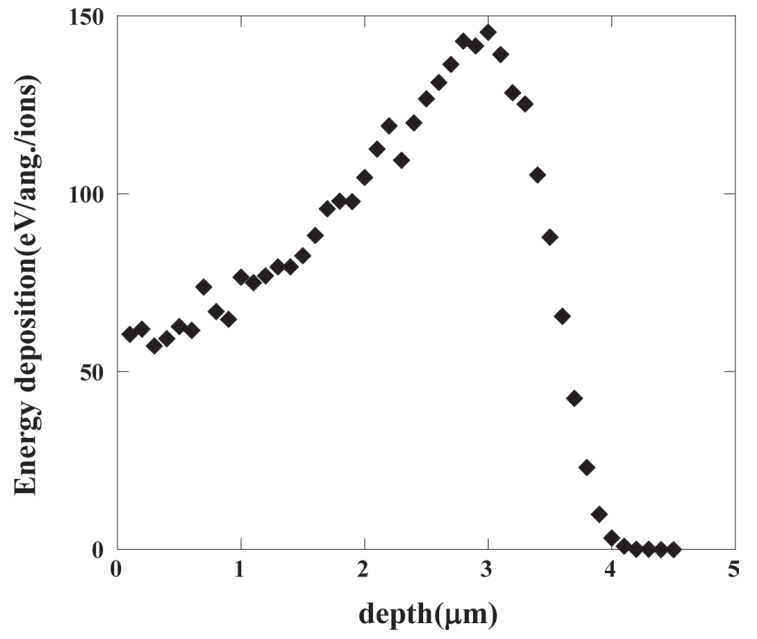

図10 SRIMコード2010を用いて計算した2017合 金への $10 \mathrm{MeV}$ よう素イオン照射における弾 性的付与エネルギーの深さ依存性



(a)

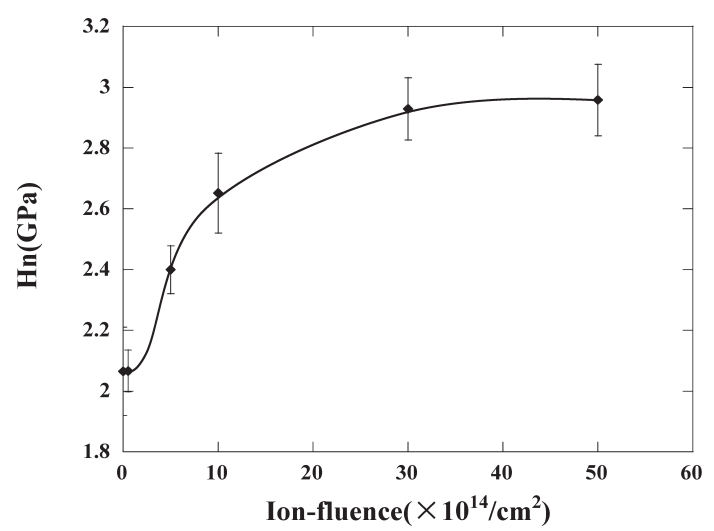

(b)

図11 よう素イオン照射した2017合金におけるナ ノインデンタ測定結果。(a) 荷重一押达み深 さ曲線，（b）表面近傍の硬さのよう素イオン 照射量依存性

分布である。よう素イオン照射によって付与される弾性的工 ネルギー，すなわち格子久陥の生成に寄与するエネルギー は，試料表面から約 $5 \mu \mathrm{m}$ までの領域に分布している。した がって，イオン照射による硬さ変化の生じる領域も，この領 域であると考えられる。それに対し，本実験で用いているマ
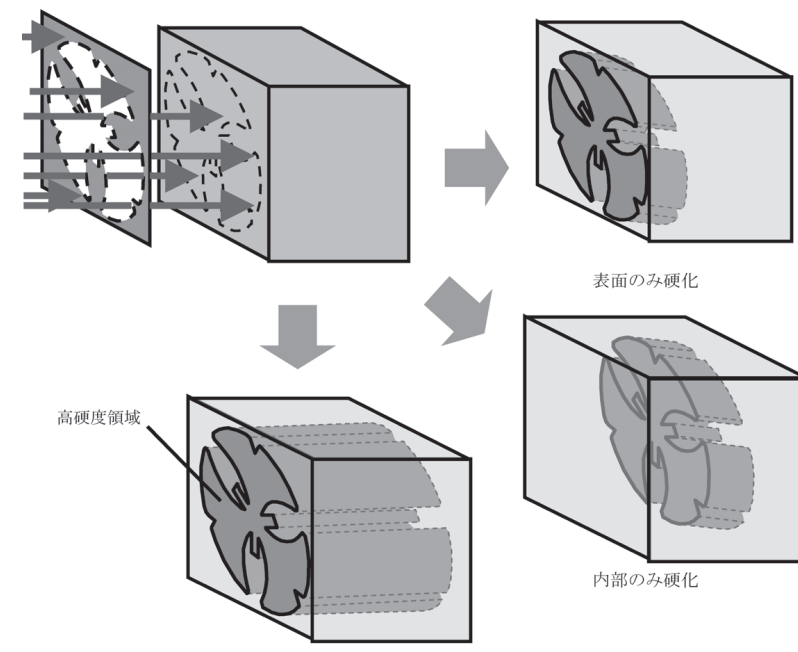

表面の外硬化

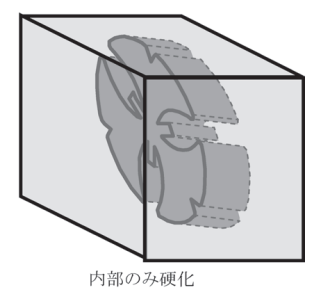

全体老硬化

図12＼cjkstart高エネルギーイオン照射による硬さ局所制 御の模式図

イクロビッカース硬さ測定では，表面から数 $10 \mu \mathrm{m}$ の領域ま で測定範囲が及んでおり, 表面近傍の照射による影響を定量 的に測定しているとは言いがたい。

そこで，表面領域の測定に有効であるナノインデンテー ション法を用いて測定を行った。その結果を図 11 に示す ${ }^{17)}$ ナノインデンテーションの詳細については参考文献 ${ }^{18), 19)}$ を 参照されたい。図11(a) は，2017合金試料において測定し た荷重変位曲線のよう素イオン照射量依存性である。圧子の 押达み深さから, 硬さ測定領域は表面から数 $100 \mathrm{~nm}$ 以下と 考えられるので, 図10で示した照射によるエネルギー付与 領域のみの硬さを測定している。荷重一定の条件での測定に おいて，照射量の増加とともに押込み深さが浅くなっている ことがわかる。これは，イオン照射により表面近傍の硬さが 増加していることにほかならない。図11(b) に, この荷重 変位曲線から算出された硬さ $(\mathrm{Hn})$ と照射量の関係を示す。 照射量が増加するに従って, ナノインデンテーションによる 硬さが増加している。これはビッカース硬さ測定と同様の傾 向を示す結果であり, 表面近傍のイオン照射によってエネル ギーが付与された領域において, 確かにイオン照射による硬 化層が形成されていることが確認できた。

本実験では，照射イオン種によう素イオンおよび，セルフ イオンであるアルミニウムイオンを用いたが，イオン照射で は，イオン種やエネルギーにより付与エネルギーの深さ分布 が異なる。図10に示したグラフで，付与エネルギーのピー ク付近で照射効果は最大になるため, イオン種やエネルギー を適当に選ぶことで試料の深さ方向の硬さ制御も可能となる であろう。つまり図12の模式図で表されるように，ある形 状のマスクを用いることにより，試料表面のある特定領域の みを硬化させたり，試料内部の特定領域のみを硬化させると いう，今までにはなかった硬さの局所制御が可能であると考 えられる。

\section{4. イオン照射と熱時効を組合せた硬さ制御 ${ }^{11}$}

以上に述べた結果から, 高エネルギーイオン照射が2017合 金において, 時効熱処理とは異なる有効な硬さ制御のツールと なることがわかった。ここでは，イオン照射を用いた硬さ制御 


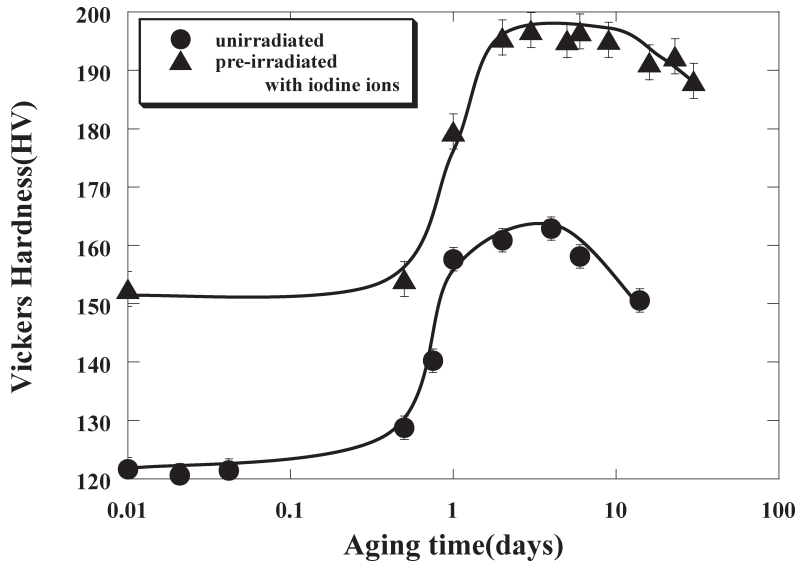

図13 $10 \mathrm{MeV}$ よう素イオン照射後, $150^{\circ} \mathrm{C}$ で熱時効 を施した2017合金の硬さのプロセス時間依 存性。比較のため, イオン照射をしないで熱 時効のみを施した試料における結果も示す。

法としての新たな可能性を探るため, イオン照射と時効熱処理 を組合せることによる硬さ特性および組織変化を論じる。

図13に，室温でエネルギー $10 \mathrm{MeV}$ のよう素イオンを照射 した試料と照射をしていない試料に対して，大気雾囲気下 $150^{\circ} \mathrm{C}$ で熱時効を施した場合のビッカース硬さ変化が，熱時 効時間の関数としてどのように変化するかを示す。わずか数 分間のよう素イオン照射を前もって行うことで，その後の熱 時効により $200 \mathrm{HV}$ に迫る硬さを得ることができる。また, イオン照射を行わない試料での通常の $150^{\circ} \mathrm{C}$ 熱時効では, ピーク硬さを得た後, 過時効による軟化が明確に観測され る。一方, 前もってイオン照射した試料における熱時効の過 程では，ピーク硬さを得た後もその硬さを一定期間保持し， その後の軟化の割合も少なくなっている。

さて，前に述べたように， $10 \mathrm{MeV}$ よう素イオン照射では， 表面数 $\mu \mathrm{m}$ 領域のみ, 照射効果が現れると考えられる。しか し，今回の測定で用いているビッカース硬さ測定では，照射 効果が及んでいない数 $10 \mu \mathrm{m}$ の深さ領域まで含んで測定して しまっている。例えば10日間熱時効した場合の測定硬さに は, 熱時効のみによる過時効現象に伴った軟化の効果も含ん で測定していることになる。以上の考察によると，表面数 $\mu \mathrm{m}$ の照射効果を受けている領域のみを考えれば，図では時 効開始20日あたりでやや軟化が起こっている付近において も試料表面での硬さは保たれる，あるいは上昇し続けるので はないかと考えられる。

次に, 前もってイオン照射を行い, その後時効熱処理を施 した試料において観測した3 次元原子マップを図14(a) に示 す。比較のため, イオン照射をしないで時効熱処理のみを 行った試料に対する 3 次元原子マップを図 14 (b) に示す。

前もってイオン照射した後熱時効を行った試料と，熱時効 のみを施した試料を比べると，添加元素の析出状態に明らか な違いが見られる。イオン照射した後熱時効を行った試料で は，イオン照射を行わないで通常の熱時効のみを施した試料 に比べ，析出物が小さく，かつ均一に分散していることがわ かる。これは以下のような析出過程を考えればうまく説明で きる。まず，図7(c) に示したように，イオン照射によって ナノメートルスケールの微細クラスタが試料全体に分散して 生成される。この試料に熱時効を施すことにより，イオン照

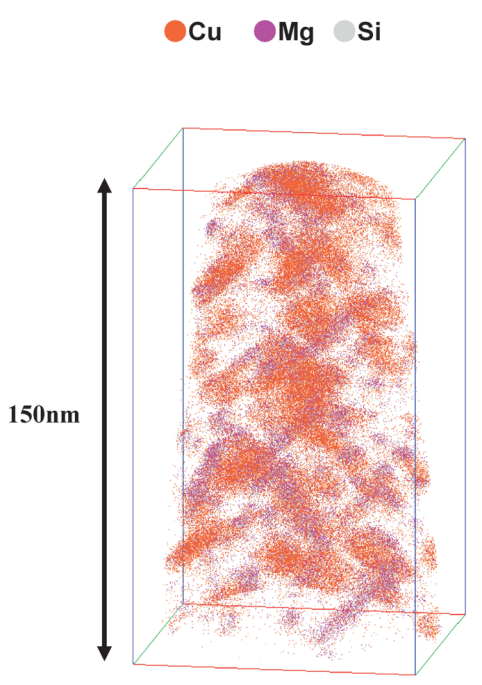

(a)

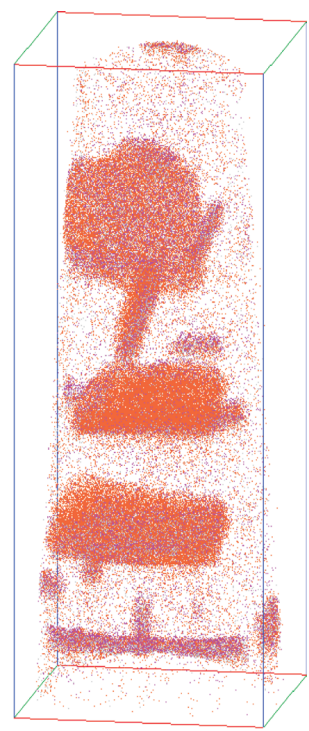

(b)
図14 アトムプローブ測定によって得られた 2017 合金の 3 次元原子マップ。(a) $10 \mathrm{MeV}$ よ素 イオンを $5.0 \times 10^{15} / \mathrm{cm}^{2}$ 照射後, $150^{\circ} \mathrm{C} ， 30$ 日 間の時効熱処理を施した試料，（b）イオン照 射を行わないで， $150^{\circ} \mathrm{C} ， 30$ 日間の時効熱処 理を施した試料

射によって生じた微細クラスタを核として析出物の成長が起 こるため, 図14(a) のような状態が得られたと考えられる。 まずイオン照射によって, ある数密度の析出核を生成してお き, 次に, 熱時効の温度や時間を制御して析出核の成長を起 こすようにすると, 最終的に, 任意の数密度と大きさをもっ た析出物分布を得ることができることを, これらの実験結果 は示唆している。添加元素析出による材料の硬さ変化は, 析 出物の数密度と大きさに大きく依存することが知られてい る。したがって，イオン照射を単独に利用するよりも，イオ ン照射とそれに続く熱時効を組合せたプロセシングを用いる ことによって，より精密で多様な硬さの制御ができると考え られるのである。また，ナノインデンテーション法を用いて イオン照射後熱時効を施した試料について測定を行った結 果, 照射量の違いにより, 硬さ変化の挙動に違いが見られた。 イオン照射によってできる微細クラスタと熱時効による析出 挙動の相互作用などは，今後調査すべき興味深い問題である。

\section{5. 各種アルミニウム合金のビッカース硬さにおけ るイオン照射効果}

ここまで，銅を主要添加元素とする2017合金のイオン照 射効果について述べてきたが, 同じ熱処理型アルミニウム合 金で銅以外の各種元素を添加させた実用合金も使われてお り，そのそれぞれについての硬さに拈けるイオン照射効果の 違いを見てみるのも大変興味深い。そこで, 本節ではSiを 主要添加元素とした 6061 合金とZnを主要添加元素とした 7075 合金に，2017合金と同じく $10 \mathrm{MeV}$ のよう素イオン照射 や $5 \mathrm{MeV}$ のアルミニウムイオン照射を行い, ビッカース硬さ 測定を行った結果について示す。JIS規格に基づく各合金の 添加元素の化学成分表を表 2 に示す。

図15は，これら 3 種類の実用合金のイオン照射によって 得られた硬さの変化の, イオンによって付与されたエネル 
表2 JIS 規格に基づく各アルミニウム合金の化学成分表

$(\operatorname{mass} \%)$

\begin{tabular}{|c|c|c|c|c|c|c|c|c|}
\hline \multirow{2}{*}{2017} & $\mathrm{Cu}$ & $\mathrm{Mn}$ & $\mathrm{Mg}$ & $\mathrm{Si}$ & $\mathrm{Fe}$ & $\mathrm{Zn}$ & $\mathrm{Cr}$ & $\mathrm{Al}$ \\
\hline & $3.5-4.5$ & $0.4-1.0$ & $0.4-0.8$ & $0.2-0.8$ & 0.7 & 0.25 & 0.1 & balanced \\
\hline \multirow{2}{*}{6061} & $\mathrm{Si}$ & $\mathrm{Mg}$ & $\mathrm{Cu}$ & $\mathrm{Mn}$ & $\mathrm{Fe}$ & $\mathrm{Zn}$ & $\mathrm{Cr}$ & $\mathrm{Al}$ \\
\hline & $0.4-0.8$ & $0.8-1.2$ & $0.15-0.4$ & 0.15 & 0.7 & 0.25 & $0.04-0.35$ & balanced \\
\hline \multirow{2}{*}{7075} & $\mathrm{Zn}$ & $\mathrm{Mg}$ & $\mathrm{Cu}$ & $\mathrm{Si}$ & $\mathrm{Mn}$ & $\mathrm{Fe}$ & $\mathrm{Cr}$ & $\mathrm{Al}$ \\
\hline & $5.1-5.6$ & $2.1-2.9$ & $1.2-2.0$ & 0.4 & 0.3 & 0.5 & $0.18-0.28$ & balanced \\
\hline
\end{tabular}

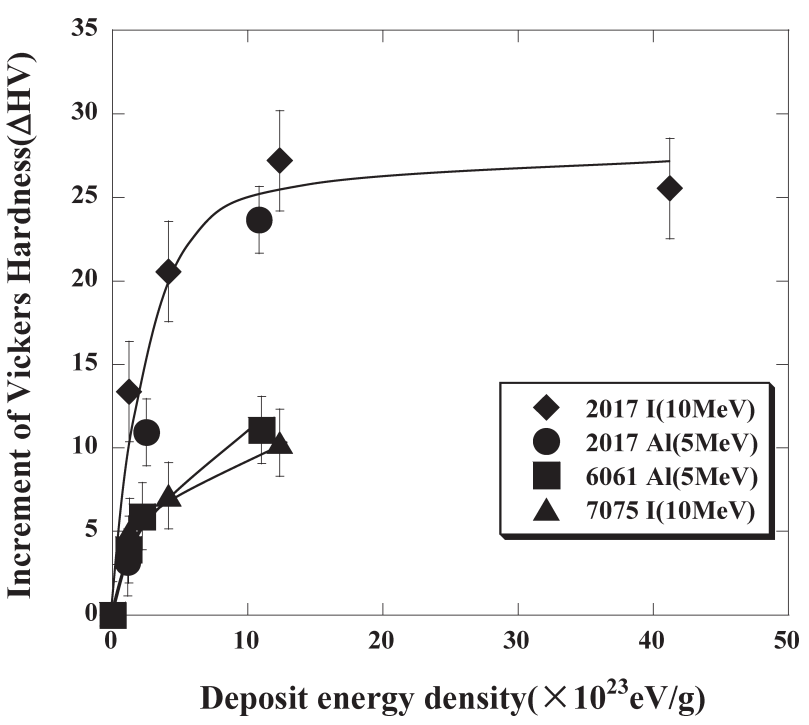

図 $152017,6061,7075$ 合金の $10 \mathrm{MeV}$ よう素イオン,

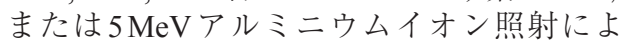
る硬さ変化の付与エネルギー密度依存性

ギー密度依存性である。すべての合金で付与エネルギー密度 の増加とともに硬さの上昇は見られるが，2017合金に比べ, 6061 合金と 7075 合金では硬さの変化量が少なくなっている。 これはイオン照射によって導入される原子空孔などの格子欠 陥と主要添加元素である $\mathrm{Si}, \mathrm{Zn}$ との相互作用が $\mathrm{Cu}$ 原子の場 合と異なるため，といった原因が考えられる20)。しかし， 各添加元素と照射欠陥との相互作用や，それによる照射促進 偏析との関係を定量的に理解するには，それぞれの二元系合 金を用いた基礎的研究を行うことが重要であり，今後調査す べき興味深い課題である。

\section{6. まと め}

2017 アルミニウム合金を室温で高エネルギーイオン照射 することにより，従来の熱時効処理と比較して，はるかに短 時間で硬さを増加させることができる。硬さの増加をもたら した主な要因は，イオン照射により試料中に生成されたナノ メートルスケールの添加元素微細クラスタである。イオン照 射した試料を熱時効処理することにより，さらに大きい硬さ が得られる。他のアルミニウム合金6061, 7075 においても同 様に，室温におけるイオン照射による硬さの増加が観測され ている。このことから, 高エネルギーイオン照射はアルミニ ウム合金試料の表面近傍の硬さ制御に適している。しかし, 残念ながら, イオンの侵入深さは数 $\mu \mathrm{m}$ に留まるため, バル ク試料全体の硬さの制御には不適である。一方，高エネル
ギー電子線は，侵入深さが mmのオーダに達するため，バル ク材料全体の硬さ制御には電子線照射が適していると考えら れる。電子線照射によるアルミニウム合金の硬さや引張強さ 測定は現在実施中である。

\section{謝 辞}

本稿の執筆にあたり，大阪府立大学・津田 大氏，金野泰 幸氏にご助言をいただきました。本稿で紹介した実験のう ち, ナノインデンタ測定は, 物質材料研究機構 大村孝仁氏 の指導で行われたものです。また，3次元アトムプローブ観 察では, 電力中央研究所 西田憲二氏, 土肥謙次氏, 曾根田 直樹氏のご協力をいただきました。また，本稿で紹介した研 究成果は, 日本原子力研究開発機構との共同研究, ならびに, 若狭湾エネルギー研究センターとの共同研究のもとで得られ たものです。

\section{参 考 文 献}

1） I. J. Polmear and S. P. Ringer：軽金属， 50 (2000)，633-642.

2）第 31 回軽金属セミナー「アルミニウム合金の時効析出一基礎 から応用まで一」，(2008）.

3）高橋恒夫, 里 達雄：軽金属, 35 (1985), 41-49.

4）廣澤渉一：軽金属, 61 (2011)，341-354。

5) S. C. Wang, M. J. Starink and N. Gao: Scr. Mater., 54 (2006), 287.

6) G. S. Was: Fundamental of Radiation Materials Science, Chapter 6, Springer, (2007).

7）石野 琹：照射損傷，東京大学出版，（1979）。

8）特集「原子炉圧力容器鋼の照射脆化機構」, 金属, 71-8 (2001), 717-770.

9) S. Nakagawa, F. Hori, Y. Chimi, N. Ishikawa, M. Kitagawa, R. Oshima, T. Tobita, R. Taniguchi, M. Suzuki and A. Iwase : Nucl. Instr. Meth., B 257 (2007), 397.

10) T. Mitsuda, I. Kobayashi, S. Kosugi, N. Fujita, Y. Saitoh, F. Hori, S. Semboshi, Y. Kaneno, K. Nishida, N. Soneda and A. Iwase : J. Nucl. Mater., 408 (2011), 201-204.

11) T. Mitsuda, I. Kobayashi, S. Kosugi, Nao. Fujita, Y. Saitoh, F. Hori, S. Semboshi, Y. Kaneno, K. Nishida, N. Soneda, S. Ishino and A. Iwase: Nucl. Instr. Meth. Phys. Res., B272 (2012), 49-52.

12）熊谷寬雄：加速器 実験物理学講座 28, 共立出版, (1975)

13) M. K. Miller, A. Cerezo, M. G. Hetherington and G. D. W. Smith: Atom Probe Field Ion Microscopy, Oxford University Press, Oxford, (1996).

14）土肥謙次, 西田憲二, 野本明義, 曾根田直樹, 渡辺英雄 : 日本 金属学会誌, 74 (2010)，191-198.

15）岩瀬彰宏: 若狭湾エネルギー研究センター 平成 21 年度共同 研究報告書 (平成 22 年 3 月)

16) J. F. Ziegler: SRIM2010 [http://www.srim.org/]

17）光田智昭，大村孝仁，金野泰幸，堀 史説，斎藤勇一，西田憲 二, 曾根田直樹, 石野 染, 岩瀬彰宏：日本金属学会第149回 講演概要, (2011)

18）大村孝仁，津崎兼彰：まてりあ，46 (2007)，251-258

19) W. C. Oliver and G. M. Pharr: J. Mater. Res., 7 (1992), 1564-1583.

20）石野 染：照射損傷，東京大学出版，(1979），主に第7章. 